Brit. Heart f., 1969, 31, 591.

\title{
Heart Rate after Combined Vagal and Sympathetic Blockade in Patients with Heart Disease
}

\author{
N. CONWAY, J. M. FOWLER, AND S. BLOOM \\ From the Department of Cardiology, Middlesex Hospital, London W.1
}

The concept of pharmacological isolation of the heart was first advanced by Jose (1966). He used the combination of propranolol and atropine injected intravenously to produce both sympathetic and vagal blockade. Under these circumstances the heart rate was reputed to become fixed, being unresponsive to sympathetic or vagal stimuli both experimentally in dogs and clinically in man. This constant heart rate was termed the "intrinsic heart rate". The duration of the period of pharmacological isolation was estimated to be at least 10 minutes after injection, with an outside limit of 20 minutes. Reporting his initial results, Jose (1966) was able to indicate normal values, the intrinsic heart rate declining progressively with age; he noted that it was raised above such predicted normal values by fever, steroids, salicylates, and effort. The onset of atrial fibrillation or its reversion to sinus rhythm did not appear to alter it. In patients with important heart disease the intrinsic heart rate was slower than expected, but clinical improvement was accompanied by a rise towards normal levels. The value of intrinsic heart rate was stated to be highly reproducible in normal subjects and this was also the experience of Frick, Heikkilä, and Kahanpää (1967).

Thus, the intrinsic heart rate appeared to offer a simple method of assessing the myocardial disorder in heart disease, both in general, as an index of change, and, in particular, as a prognostic test for patients undergoing valve replacement. However, preliminary observations of intrinsic heart rate for these purposes showed poor consistency, and in view of this and some ambiguity about the exact period of pharmacological isolation, a study of the reproducibility of the intrinsic heart rate was undertaken.

Received January 13, 1969.

\section{SUBJECTS AND METHODS}

Nineteen patients ( 7 men and 12 women) aged between 17 and 55 years (mean 38.2 years) were studied. Seven (Cases 1, 2, 3, 12, 13, 14, and 15) had atrial fibrillation and valvar heart disease; the rest were in sinus rhythm with the following lesions: valvar heart disease (Cases 4, 5, 6, 7, and 8), coronary heart disease (Cases 9 and 10), cardiomyopathy (Case 11), and uncomplicated atrial septal defect (Cases 16, 17, 18, and 19).

All the patients were studied at least 4 days after admission to hospital. The test was performed on consecutive days and at the same time of day so that 24 hours were allowed for elimination of previously injected atropine and propranolol before the next test. Three tests on successive days were obtained in 13 patients and two tests in another (Case 14). Two patients (Cases 10 and 15) were studied once only because of unpleasant side-effects after the first investigation. The remaining 3 patients (Cases 1, 2, and 3) were those incompletely studied before the start of the formal investigation. Their heart rate was counted in the same manner as the later patients but for single minutes only on the first day. These 3 patients also had only two tests in all.

No patient was febrile at any point during or immediately before the study. None were in heart failure nor had been in failure within the previous two months. Eight were receiving digitalis and diuretics (Cases 1, 2, 3, $4,12,13,14$, and 15). The dose of these drugs had not changed for at least two weeks beforehand in each case and was not altered during the period of study. No other drugs were given. Clinically, no patient's condition changed during the three days of their investigation. Each patient was weighed daily and no significant change occurred in any of them.

Before each test the patient rested in bed for at least 30 minutes. To overcome difficulties in counting the heart rate, a continuous electrocardiographic strip running at a slow speed was used. Exact timing was achieved with a stop-watch and the electrocardiographic strip marked at minute intervals. By agreed convention QRS complexes falling on the minute mark were included in the total of the following minute. In this 591 
occurred, were added to the appropriate minute's total. After recording the heart rate for a control period of one minute, propranolol $0.2 \mathrm{mg}$. and atropine $0.04 \mathrm{mg} / \mathrm{kg}$. body weight were mixed and injected intravenously over a timed two-minute period, as described by Jose (1966). The first minute after injection was ignored, and counting of the heart rate was begun at the start of the second minute. It was continued for 14 minutes (i.e. until the end of the 15th minute after injection). Patients were confined to bed for 4 hours afterwards, half-hourly blood pressure recordings being taken.

\section{RESULTS}

The results shown in Table I are analysed in two respects. First, the constancy of the heart rate after injection; second, comparison between successive tests in each individual.

TABLE I

HEART RATES (BEATS MINUTE) FOR 15 MINUTES AFTER INTRAVENOUS INJECTION OF PROPRANOLOL 0.2 MG. AND ATROPINE 0.04 MG. KG. BODY WEIGHT

\begin{tabular}{|c|c|c|c|c|c|c|c|c|c|c|c|c|c|c|c|c|c|}
\hline \multirow{2}{*}{$\begin{array}{l}\text { Case } \\
\text { No. }\end{array}$} & \multicolumn{2}{|c|}{ Dose (mg.) } & \multirow[b]{2}{*}{ Control } & \multicolumn{14}{|c|}{ Minutes after injection } \\
\hline & $\begin{array}{c}\text { Propran- } \\
\text { olol }\end{array}$ & Atropine & & $1-2$ & $2-3$ & $3-4$ & $4-5$ & $5-6$ & $6-7$ & $7-8$ & $8-9$ & $9-10$ & $10-11$ & $11-12$ & $12-13$ & $13-14$ & $14-15$ \\
\hline 1 & $9 \cdot 5$ & $1 \cdot 9$ & $\begin{array}{r}103 \\
95\end{array}$ & $\overline{100}$ & $\begin{array}{l}94 \\
96\end{array}$ & $\overline{96}$ & $\overline{93}$ & $\begin{array}{l}89 \\
93\end{array}$ & $\overline{92}$ & $\begin{array}{l}89 \\
92\end{array}$ & $\overline{91}$ & $\begin{array}{l}88 \\
91\end{array}$ & $\begin{array}{l}86 \\
90\end{array}$ & $\overline{89}$ & $\overline{90}$ & $\overline{89}$ & $\overline{89}$ \\
\hline 2 & $9 \cdot 0$ & 1.8 & $\begin{array}{l}78 \\
65\end{array}$ & $\overline{76}$ & $\begin{array}{l}79 \\
71\end{array}$ & $\overline{69}$ & $\overline{67}$ & $\overline{68}$ & $\begin{array}{l}67 \\
66\end{array}$ & $\overline{66}$ & $\begin{array}{l}62 \\
67\end{array}$ & $\overline{64}$ & $\begin{array}{l}65 \\
62\end{array}$ & $\overline{65}$ & $\overline{60}$ & $\begin{array}{l}59 \\
62\end{array}$ & $\overline{61}$ \\
\hline 3 & $9 \cdot 2$ & $1 \cdot 8$ & $\begin{array}{r}107 \\
96\end{array}$ & $\overline{99}$ & $\overline{90}$ & $\begin{array}{l}91 \\
91\end{array}$ & $\overline{89}$ & $\begin{array}{l}83 \\
90\end{array}$ & $\overline{88}$ & $\overline{83}$ & $\begin{array}{l}91 \\
79\end{array}$ & $\overline{79}$ & $\overline{78}$ & $\begin{array}{l}90 \\
78\end{array}$ & $\overline{78}$ & $\overline{78}$ & $\overline{79}$ \\
\hline 4 & $10 \cdot 0$ & $2 \cdot 0$ & $\begin{array}{l}84 \\
85 \\
94\end{array}$ & $\begin{array}{l}83 \\
82 \\
80\end{array}$ & $\begin{array}{l}81 \\
81 \\
78\end{array}$ & $\begin{array}{l}80 \\
79 \\
77\end{array}$ & $\begin{array}{l}80 \\
80 \\
76\end{array}$ & $\begin{array}{l}79 \\
79 \\
76\end{array}$ & $\begin{array}{l}78 \\
78 \\
76\end{array}$ & $\begin{array}{l}78 \\
78 \\
74\end{array}$ & $\begin{array}{l}79 \\
78 \\
76\end{array}$ & $\begin{array}{l}78 \\
78 \\
74\end{array}$ & $\begin{array}{l}78 \\
78 \\
75\end{array}$ & $\begin{array}{l}78 \\
78 \\
74\end{array}$ & $\begin{array}{l}78 \\
77 \\
74\end{array}$ & $\begin{array}{l}78 \\
76 \\
74\end{array}$ & $\begin{array}{l}78 \\
77 \\
74\end{array}$ \\
\hline 5 & $10 \cdot 4$ & $2 \cdot 1$ & $\begin{array}{l}80 \\
67 \\
83\end{array}$ & $\begin{array}{l}98 \\
89 \\
94\end{array}$ & $\begin{array}{l}98 \\
89 \\
94\end{array}$ & $\begin{array}{l}97 \\
91 \\
94\end{array}$ & $\begin{array}{l}97 \\
91 \\
93\end{array}$ & $\begin{array}{l}97 \\
91 \\
94\end{array}$ & $\begin{array}{l}98 \\
91 \\
94\end{array}$ & $\begin{array}{l}99 \\
91 \\
94\end{array}$ & $\begin{array}{r}101 \\
90 \\
94\end{array}$ & $\begin{array}{l}98 \\
91 \\
92\end{array}$ & $\begin{array}{l}97 \\
91 \\
93\end{array}$ & $\begin{array}{l}97 \\
92 \\
94\end{array}$ & $\begin{array}{l}98 \\
91 \\
94\end{array}$ & $\begin{array}{l}97 \\
90 \\
92\end{array}$ & $\begin{array}{l}96 \\
91 \\
91\end{array}$ \\
\hline 6 & $11 \cdot 1$ & $2 \cdot 2$ & $\begin{array}{l}54 \\
55 \\
72\end{array}$ & $\begin{array}{r}101 \\
97 \\
97\end{array}$ & $\begin{array}{l}99 \\
97 \\
97\end{array}$ & $\begin{array}{l}99 \\
97 \\
96\end{array}$ & $\begin{array}{l}99 \\
98 \\
96\end{array}$ & $\begin{array}{l}98 \\
98 \\
97\end{array}$ & $\begin{array}{l}98 \\
97 \\
96\end{array}$ & $\begin{array}{l}99 \\
97 \\
96\end{array}$ & $\begin{array}{l}97 \\
97 \\
96\end{array}$ & $\begin{array}{l}98 \\
96 \\
96\end{array}$ & $\begin{array}{l}97 \\
96 \\
95\end{array}$ & $\begin{array}{l}97 \\
96 \\
95\end{array}$ & $\begin{array}{l}97 \\
96 \\
95\end{array}$ & $\begin{array}{l}97 \\
96 \\
95\end{array}$ & $\begin{array}{l}96 \\
94 \\
95\end{array}$ \\
\hline 7 & $17 \cdot 2$ & $3 \cdot 4$ & $\begin{array}{l}84 \\
58 \\
65\end{array}$ & $\begin{array}{l}97 \\
91 \\
91\end{array}$ & $\begin{array}{l}95 \\
90 \\
90\end{array}$ & $\begin{array}{l}94 \\
89 \\
89\end{array}$ & $\begin{array}{l}93 \\
88 \\
88\end{array}$ & $\begin{array}{l}92 \\
88 \\
89\end{array}$ & $\begin{array}{l}92 \\
88 \\
88\end{array}$ & $\begin{array}{l}91 \\
86 \\
87\end{array}$ & $\begin{array}{l}92 \\
87 \\
87\end{array}$ & $\begin{array}{l}91 \\
86 \\
87\end{array}$ & $\begin{array}{l}92 \\
86 \\
86\end{array}$ & $\begin{array}{l}91 \\
85 \\
86\end{array}$ & $\begin{array}{l}92 \\
85 \\
85\end{array}$ & $\begin{array}{l}92 \\
85 \\
85\end{array}$ & $\begin{array}{l}91 \\
85 \\
84\end{array}$ \\
\hline 8 & $16 \cdot 0$ & $3 \cdot 3$ & $\begin{array}{l}78 \\
71 \\
76\end{array}$ & $\begin{array}{l}90 \\
82 \\
85\end{array}$ & $\begin{array}{l}86 \\
81 \\
83\end{array}$ & $\begin{array}{l}85 \\
79 \\
82\end{array}$ & $\begin{array}{l}86 \\
79 \\
81\end{array}$ & $\begin{array}{l}84 \\
78 \\
81\end{array}$ & $\begin{array}{l}83 \\
79 \\
81\end{array}$ & $\begin{array}{l}82 \\
78 \\
80\end{array}$ & $\begin{array}{l}82 \\
78 \\
80\end{array}$ & $\begin{array}{l}82 \\
78 \\
82\end{array}$ & $\begin{array}{l}82 \\
77 \\
81\end{array}$ & $\begin{array}{l}82 \\
78 \\
80\end{array}$ & $\begin{array}{l}82 \\
78 \\
79\end{array}$ & $\begin{array}{l}82 \\
77 \\
80\end{array}$ & $\begin{array}{l}81 \\
77 \\
80\end{array}$ \\
\hline 9 & $12 \cdot 8$ & $2 \cdot 6$ & $\begin{array}{l}90 \\
85 \\
79\end{array}$ & $\begin{array}{l}88 \\
83 \\
81\end{array}$ & $\begin{array}{l}83 \\
80 \\
80\end{array}$ & $\begin{array}{l}82 \\
80 \\
78\end{array}$ & $\begin{array}{l}79 \\
78 \\
79\end{array}$ & $\begin{array}{l}80 \\
78 \\
78\end{array}$ & $\begin{array}{l}79 \\
79 \\
78\end{array}$ & $\begin{array}{l}79 \\
78 \\
78\end{array}$ & $\begin{array}{l}78 \\
78 \\
77\end{array}$ & $\begin{array}{l}79 \\
78 \\
78\end{array}$ & $\begin{array}{l}78 \\
78 \\
76\end{array}$ & $\begin{array}{l}79 \\
78 \\
78\end{array}$ & $\begin{array}{l}78 \\
78 \\
77\end{array}$ & $\begin{array}{l}78 \\
77 \\
78\end{array}$ & $\begin{array}{l}78 \\
78 \\
77\end{array}$ \\
\hline 10 & $16 \cdot 8$ & $3 \cdot 4$ & 88 & 93 & 91 & 91 & 90 & 90 & 90 & 90 & 89 & 90 & 89 & 89 & 89 & 88 & 89 \\
\hline 11 & $10 \cdot 2$ & $2 \cdot 0$ & $\begin{array}{l}78 \\
67 \\
73\end{array}$ & $\begin{array}{l}92 \\
99 \\
90\end{array}$ & $\begin{array}{r}92 \\
100 \\
89\end{array}$ & $\begin{array}{r}91 \\
103 \\
87\end{array}$ & $\begin{array}{r}89 \\
104 \\
88\end{array}$ & $\begin{array}{r}90 \\
103 \\
87\end{array}$ & $\begin{array}{r}90 \\
103 \\
87\end{array}$ & $\begin{array}{r}89 \\
102 \\
87\end{array}$ & $\begin{array}{r}90 \\
103 \\
87\end{array}$ & $\begin{array}{r}90 \\
103 \\
85\end{array}$ & $\begin{array}{r}90 \\
104 \\
85\end{array}$ & $\begin{array}{r}89 \\
102 \\
86\end{array}$ & $\begin{array}{r}91 \\
101 \\
85\end{array}$ & $\begin{array}{r}91 \\
101 \\
85\end{array}$ & $\begin{array}{r}89 \\
100 \\
84\end{array}$ \\
\hline 12 & $10 \cdot 4$ & $2 \cdot 1$ & $\begin{array}{l}88 \\
75 \\
87\end{array}$ & $\begin{array}{l}84 \\
80 \\
87\end{array}$ & $\begin{array}{l}83 \\
79 \\
86\end{array}$ & $\begin{array}{r}83 \\
78 \\
. \quad 86\end{array}$ & $\begin{array}{l}83 \\
78 \\
84\end{array}$ & $\begin{array}{l}82 \\
77 \\
85\end{array}$ & $\begin{array}{l}82 \\
79 \\
83\end{array}$ & $\begin{array}{l}83 \\
77 \\
84\end{array}$ & $\begin{array}{l}82 \\
79 \\
83\end{array}$ & $\begin{array}{l}80 \\
78 \\
80\end{array}$ & $\begin{array}{l}80 \\
78 \\
82\end{array}$ & $\begin{array}{l}81 \\
79 \\
82\end{array}$ & $\begin{array}{l}78 \\
79 \\
81\end{array}$ & $\begin{array}{l}81 \\
78 \\
81\end{array}$ & $\begin{array}{l}80 \\
76 \\
79\end{array}$ \\
\hline 13 & $15 \cdot 5$ & $3 \cdot 1$ & $\begin{array}{l}58 \\
56 \\
68\end{array}$ & $\begin{array}{l}73 \\
79 \\
82\end{array}$ & $\begin{array}{l}72 \\
78 \\
83\end{array}$ & $\begin{array}{l}73 \\
77 \\
81\end{array}$ & $\begin{array}{l}72 \\
78 \\
82\end{array}$ & $\begin{array}{l}70 \\
74 \\
81\end{array}$ & $\begin{array}{l}72 \\
77 \\
82\end{array}$ & $\begin{array}{l}72 \\
69 \\
80\end{array}$ & $\begin{array}{l}71 \\
73 \\
80\end{array}$ & $\begin{array}{l}70 \\
78 \\
79\end{array}$ & $\begin{array}{l}70 \\
70 \\
78\end{array}$ & $\begin{array}{l}69 \\
75 \\
81\end{array}$ & $\begin{array}{l}68 \\
74 \\
78\end{array}$ & $\begin{array}{l}71 \\
77 \\
79\end{array}$ & $\begin{array}{l}70 \\
71 \\
77\end{array}$ \\
\hline 14 & $17 \cdot 2$ & $3 \cdot 4$ & $\begin{array}{l}96 \\
84\end{array}$ & $\begin{array}{l}91 \\
87\end{array}$ & $\begin{array}{l}90 \\
85\end{array}$ & $\begin{array}{l}93 \\
84\end{array}$ & $\begin{array}{l}79 \\
86\end{array}$ & $\begin{array}{l}82 \\
81\end{array}$ & $\begin{array}{l}76 \\
81\end{array}$ & $\begin{array}{l}80 \\
88\end{array}$ & $\begin{array}{l}85 \\
83\end{array}$ & $\begin{array}{l}81 \\
83\end{array}$ & $\begin{array}{l}82 \\
85\end{array}$ & $\begin{array}{l}81 \\
77\end{array}$ & $\begin{array}{l}77 \\
85\end{array}$ & $\begin{array}{l}80 \\
79\end{array}$ & $\begin{array}{l}85 \\
81\end{array}$ \\
\hline 15 & 14.5 & $2 \cdot 9$ & 64 & 72 & 65 & 64 & 63 & 61 & 63 & 60 & 60 & 57 & 57 & 56 & 58 & 58 & 60 \\
\hline 16 & $15 \cdot 5$ & $3 \cdot 1$ & $\begin{array}{l}59 \\
88 \\
55\end{array}$ & $\begin{array}{l}72 \\
76 \\
78\end{array}$ & $\begin{array}{l}69 \\
74 \\
77\end{array}$ & $\begin{array}{l}68 \\
73 \\
76\end{array}$ & $\begin{array}{l}68 \\
73 \\
75\end{array}$ & $\begin{array}{l}67 \\
72 \\
75\end{array}$ & $\begin{array}{l}67 \\
74 \\
75\end{array}$ & $\begin{array}{l}67 \\
75 \\
73\end{array}$ & $\begin{array}{l}66 \\
75 \\
73\end{array}$ & $\begin{array}{l}67 \\
74 \\
77\end{array}$ & $\begin{array}{l}66 \\
75 \\
77\end{array}$ & $\begin{array}{l}65 \\
75 \\
72\end{array}$ & $\begin{array}{l}67 \\
74 \\
71\end{array}$ & $\begin{array}{l}66 \\
74 \\
72\end{array}$ & $\begin{array}{l}66 \\
75 \\
71\end{array}$ \\
\hline 17 & $10 \cdot 2$ & $2 \cdot 0$ & $\begin{array}{l}87 \\
76 \\
78\end{array}$ & $\begin{array}{l}96 \\
95 \\
95\end{array}$ & $\begin{array}{l}95 \\
95 \\
95\end{array}$ & $\begin{array}{l}95 \\
95 \\
94\end{array}$ & $\begin{array}{l}96 \\
95 \\
93\end{array}$ & $\begin{array}{l}97 \\
96 \\
93\end{array}$ & $\begin{array}{l}97 \\
95 \\
93\end{array}$ & $\begin{array}{l}97 \\
97 \\
92\end{array}$ & $\begin{array}{l}95 \\
94 \\
91\end{array}$ & $\begin{array}{l}95 \\
95 \\
92\end{array}$ & $\begin{array}{l}95 \\
95 \\
90\end{array}$ & $\begin{array}{l}91 \\
94 \\
90\end{array}$ & $\begin{array}{l}96 \\
94 \\
92\end{array}$ & $\begin{array}{l}94 \\
93 \\
91\end{array}$ & $\begin{array}{l}93 \\
93 \\
90\end{array}$ \\
\hline 18 & $9 \cdot 6$ & $1 \cdot 9$ & $\begin{array}{l}81 \\
84 \\
81\end{array}$ & $\begin{array}{l}104 \\
106 \\
104\end{array}$ & $\begin{array}{l}102 \\
104 \\
102\end{array}$ & $\begin{array}{l}102 \\
103 \\
101\end{array}$ & $\begin{array}{l}101 \\
103 \\
101\end{array}$ & $\begin{array}{l}100 \\
102 \\
101\end{array}$ & $\begin{array}{l}101 \\
103 \\
101\end{array}$ & $\begin{array}{r}100 \\
102 \\
99\end{array}$ & $\begin{array}{l}101 \\
100 \\
100\end{array}$ & $\begin{array}{c}98 \\
101 \\
99\end{array}$ & $\begin{array}{r}100 \\
101 \\
99\end{array}$ & $\begin{array}{r}99 \\
99 \\
100\end{array}$ & $\begin{array}{r}99 \\
101 \\
99\end{array}$ & $\begin{array}{l}98 \\
98 \\
99\end{array}$ & $\begin{array}{l}98 \\
99 \\
99\end{array}$ \\
\hline 19 & 8.0 & $1 \cdot 6$ & $\begin{array}{l}96 \\
92 \\
92\end{array}$ & $\begin{array}{l}99 \\
94 \\
95\end{array}$ & $\begin{array}{l}99 \\
92 \\
94\end{array}$ & $\begin{array}{l}97 \\
92 \\
93\end{array}$ & $\begin{array}{l}96 \\
92 \\
93\end{array}$ & $\begin{array}{l}97 \\
91 \\
92\end{array}$ & $\begin{array}{l}96 \\
91 \\
93\end{array}$ & $\begin{array}{l}96 \\
92 \\
91\end{array}$ & $\begin{array}{l}95 \\
91 \\
92\end{array}$ & $\begin{array}{l}94 \\
90 \\
92\end{array}$ & $\begin{array}{l}94 \\
92 \\
91\end{array}$ & $\begin{array}{l}95 \\
91 \\
91\end{array}$ & $\begin{array}{l}96 \\
91 \\
91\end{array}$ & $\begin{array}{l}97 \\
91 \\
91\end{array}$ & $\begin{array}{l}97 \\
91 \\
90\end{array}$ \\
\hline
\end{tabular}


Constancy of Heart Rate after Injection. The exact time of onset of the period of pharmacological isolation after this injection of propranolol and atropine has not been clearly established in previous work. Jose (1966) suggests that at 5 minutes "after injection" (presumptively the end of injection as in this study) isolation may be assumed; Frick et al. (1967) used 3 minutes after injection. Examination of our data (Table I) suggested the compromise of 4 minutes, since in nearly all cases the heart rate during this minute resembles subsequent values fairly closely. The heart rate during this minute (4-5 in Table I) has accordingly been used as the reference point for comparison purposes, but an earlier point could have been used in most subjects. If the onset of pharmacological isolation is not established, its duration is equally uncertain. Jose (1966) suggests 10 to 20 minutes after injection. Again, we have compromised at 15 minutes.

During this period, from the beginning of the 4th to the end of the 15th minute after injection, the heart rate declined slowly in many instances. It showed a tendency to rise in 4 or 5 tests only. The resultant effect for all subjects, therefore, was a small progressive decline. While in many patients the heart rate was remarkably steady, in others it was more variable (e.g. Cases $2,3,14,15)$. Some patients had heart rates that were constant on one occasion but variable on another (e.g. Cases 5 and 13). If a "constant" rate is defined as permitting a deviation of 4 beats/minute in either direction from the initial 4-5 minute level, then this occurred in 34 of the 46 complete results (i.e. excluding the first (incomplete) test in Cases 1-3). This leaves 6 tests with at least one reading differing by 5 beats from the initial value (Cases $8 \mathrm{i}^{\star}, 12 \mathrm{i}$ and iii, $13 \mathrm{iii}, 17 \mathrm{i}$, and $18 \mathrm{ii}$ ) and, if the incomplete results in Cases 1-3 are included, 8 more with a greater maximum difference (Case $14 \mathrm{i}-6$ beats; Cases 2 ii, $3 \mathrm{i}$, and $15-7$ beats; Case $2 \mathrm{i}-8$ beats; Cases 13 ii and 14 ii-9 beats; Cases 3 ii-11 beats). Most of the variability in heart rate occurred between 10 and 15 minutes after injection. If, therefore, the period under analysis is shortened to 4 10 minutes after injection a constant rate (within 4 beats of the value at 4-5 minutes) is present in 42 tests but 7 other results in 5 patients still transgress this limit (Cases $2 \mathrm{i}, 3 \mathrm{i}$ and ii, $13 \mathrm{ii}, 14 \mathrm{i}$ and ii, and 15). These 5 patients all had atrial fibrillation.

Comparison Between Different Tests in Same Individual. Once again, the period 4-15 minutes after injection was studied. Heart rates during the second and third tests were compared with

\footnotetext{
$\star$ The suffix $\mathrm{i}$, ii, or iii after a Case number refers to the first,
} second, or third test on that patient.
TABLE II

DIFFERENCES IN HEART RATE (BEATS PER MINUTE) BETWEEN PAIRS OF TESTS AT EACH MINUTE FROM 4 TO 15 MINUTES AFTER INJECTION

\begin{tabular}{|c|c|c|c|c|}
\hline \multirow{2}{*}{$\begin{array}{l}\text { Case } \\
\text { No. }\end{array}$} & \multicolumn{2}{|c|}{$\begin{array}{l}\text { 2nd test compared to } \\
\text { 1st test }\end{array}$} & \multicolumn{2}{|c|}{$\begin{array}{l}\text { 3rd test compared to } \\
1 \text { st test }\end{array}$} \\
\hline & Range* & Mean ${ }^{\star}$ & Range & Mean* \\
\hline $\begin{array}{l}1 \\
2 \\
3 \\
4 \\
5 \\
6 \\
7 \\
8 \\
9 \\
11 \\
12 \\
13 \\
14 \\
16 \\
17 \\
18 \\
19\end{array}$ & $\begin{array}{l}+3 \text { to }+4 t \\
-1 \text { to }+5 t \\
-12 \text { to }+7 \ddagger \\
-2 \text { to } 0 \\
-11 \text { to }-5 \\
-2 \text { to } 0 \\
-7 \text { to }-4 \\
-7 \text { to }-4 \\
-2 \text { to } 0 \\
+10 \text { to }+15 \\
-6 \text { to }+1 \\
-3 \text { to }+8 \\
-1 \text { to }+8 \\
+5 \text { to }+10 \\
-1 \text { to }+3 \\
-1 \text { to }+3 \\
-6 \text { to }-2\end{array}$ & $\begin{array}{r}3.5 \\
3.0 \\
10 \cdot 3 \\
0.5 \\
6.8 \\
1.1 \\
5.5 \\
4.7 \\
0.6 \\
12.5 \\
3.3 \\
4.3 \\
4.2 \\
7.6 \\
1.0 \\
1.5 \\
4.5\end{array}$ & $\begin{array}{c}\text { 二 } \\
-2 \text { to }-4 \\
-3 \text { to }-7 \\
-3 \text { to }-1 \\
-7 \text { to }-3 \\
-5 \text { to }-1 \\
-2 \text { to } 0 \\
-6 \text { to }-1 \\
-1 \text { to }+3 \\
+7 \text { to }+12 \\
+4 \text { to }+11 \\
-5 \text { to }-1 \\
-1 \text { to }+1 \\
-7 \text { to }-2\end{array}$ & $\begin{array}{l}= \\
= \\
3 \cdot 5 \\
4.5 \\
2 \cdot 1 \\
5.3 \\
2 \cdot 2 \\
1.0 \\
3 \cdot 8 \\
1.3 \\
9 \cdot 3 \\
7 \cdot 2 \\
3 \cdot 5 \\
0.7 \\
4 \cdot 2\end{array}$ \\
\hline
\end{tabular}

$\star 11$ observations. +4 observations only. $¥ 3$ observations only.

those at the same time after injection during the first test. The range of variation and mean values are given in Table II. A few subjects showed very similar rates on all three occasions (e.g. Cases 6, 9, and 18); others agreed on two out of three occasions (e.g. Cases 7, 16, and 17), and some showed no close agreement (e.g. Cases 5, 11, and 13). The order of tests did not appear to have any influence in this respect nor did the presence of atrial fibrillation. If reasonable agreement is defined as permitting a difference of 4 beats a minute in either direction between successive tests, the number of subjects and the number of matched minute totals falling outside this limit is considerable and details are given in Table III. Restricting the comparison to the period 4-10 minutes after injection, on the ground that heart rates in individual tests were, in general, more constant during this period (vide supra), fails to improve agreement.

These differences between successive tests in several subjects were disappointing and, in order to minimize the effect of the slow decline in heart rate during the course of many tests and the minuteto-minute variations in rate already described, mean values were derived covering 5 -minute periods from 5-10 and 10-15 minutes after injection. These are shown in Table IV. This manoeuvre improves the agreement between successive tests in several subjects, but not in all (e.g. Cases 5, 7, 11, 13, 16, and 19). If, once again, a difference of 4 beats is allowed between paired values in each 5 minute period, 6 out of 14 subjects transgress this limit when first and second tests are compared and 5 out of 13 subjects when first and third tests are compared. Four subjects (Cases 5, 11, 13, and 16) show differences ranging between 6 and 17 beats a 
TABLE III

COMPARISON OF SUCCESSIVE TESTS: DISAGREEMENT OF 5 BEATS PER MINUTE OR MORE

\begin{tabular}{c|c|c|c|c|c|c}
\hline \multirow{2}{*}{$\begin{array}{c}\text { Tests } \\
\text { compared }\end{array}$} & \multicolumn{2}{|c|}{$\begin{array}{c}\text { Subjects showing } \\
\text { disagreement on at least } \\
\text { one occasion }\end{array}$} & \multicolumn{2}{|c|}{ Matched single minutes after injection } \\
\cline { 2 - 6 } & Total & Disagreement & Total & Disagreement & Total & Disagreement \\
\hline 1 and 2 & 17 & 11 & 91 & $39(43 \%)$ & 166 & $70(42 \%)$ \\
1 and 3 & 13 & 8 & 78 & $22(28 \%)$ & 148 & $46(32 \%)$ \\
\hline
\end{tabular}

* Values for 4 to 10 and 4 to 15 minutes after injection are identical.

TABLE IV

COMPARISON OF MEAN VALUES OF HEART RATE (BEATS/MINUTE) FOR TWO 5-MINUTE PERIODS

\begin{tabular}{|c|c|c|c|c|c|c|}
\hline \multirow{3}{*}{$\begin{array}{l}\text { Case } \\
\text { No. }\end{array}$} & \multicolumn{6}{|c|}{ Period after injection } \\
\hline & \multicolumn{3}{|c|}{ 5-10 minutes } & \multicolumn{3}{|c|}{ 10-15 minutes } \\
\hline & 1st test & 2nd test & 3rd test & 1st test & 2nd test & 3rd test \\
\hline $\begin{array}{r}4 \\
5 \\
6 \\
7 \\
8 \\
9 \\
11 \\
12 \\
13 \\
14 \\
16 \\
17 \\
18 \\
19\end{array}$ & $\begin{array}{r}78 \\
99 \\
98 \\
92 \\
83 \\
79 \\
90 \\
82 \\
71 \\
81 \\
67 \\
96 \\
100 \\
96\end{array}$ & $\begin{array}{r}78 \\
91 \\
97 \\
87 \\
78 \\
78 \\
103 \\
78 \\
74 \\
83 \\
74 \\
95 \\
102 \\
91\end{array}$ & $\begin{array}{r}75 \\
94 \\
96 \\
87 \\
81 \\
78 \\
87 \\
83 \\
80 \\
75 \\
92 \\
100 \\
92\end{array}$ & $\begin{array}{l}78 \\
97 \\
97 \\
92 \\
82 \\
78 \\
90 \\
80 \\
70 \\
79 \\
66 \\
94 \\
99 \\
96\end{array}$ & $\begin{array}{r}77 \\
91 \\
96 \\
85 \\
77 \\
78 \\
102 \\
78 \\
73 \\
81 \\
75 \\
94 \\
100 \\
91\end{array}$ & $\begin{array}{l}74 \\
93 \\
95 \\
85 \\
80 \\
77 \\
85 \\
81 \\
79 \\
73 \\
91 \\
99 \\
91\end{array}$ \\
\hline
\end{tabular}

minute. Once again, confining such analysis to the earlier period (from 5-10 minutes in this instance) makes little difference. Because of incomplete results, Cases 1-3 are of necessity excluded from consideration in this manner.

Side-effects of Injection. All subjects experienced a dry mouth and, to some degree, blurred vision for several hours. Several were dizzy. Most showed a moderate drop in systolic blood pressure (10-30 $\mathrm{mm} . \mathrm{Hg}$ ), but this was not surprising during an enforced period of bed-rest. Two patients showed larger falls in blood pressure. In one (Case 10) the blood pressure fell from $120 / 75$ to $60 / 40 \mathrm{~mm}$. $\mathrm{Hg}$. In the other (Case 15) hypotension was followed by the appearance of ischaemic changes in the resting electrocardiogram. No further tests were carried out on these two patients.

\section{Discussion}

These results show that after pharmacological isolation (or near isolation) of the abnormal heart by intravenous propranolol and atropine, as described by Jose (1966), the heart rate becomes relatively "fixed" in only a proportion of subjects. In others the heart rate varies and this appears more likely to occur in patients with atrial fibrillation.
In the majority of cases, too, the heart rate, after apparently settling at about 5 minutes after injection, subsequently continues to decline gently.

The intrinsic heart rate has been found by Jose (1966) to be highly reproducible in normal subjects. He indicated a standard deviation of \pm 2 per cent, but it is not entirely clear whether this refers to multiple readings on a single occasion, to repeated separate observations, or to both. Frick et al. (1967) carried out duplicate tests on 18 subjects 1 to 5 days apart and found a mean difference of 2.8 beats a minute (range not published), but it is not stated if these patients had heart disease or not. In the present study, despite a careful attempt to avoid any of the factors known to alter intrinsic heart rate (such as clinical improvement or deterioration, changes in drug therapy, fever, and effort) less consistent figures were obtained. Of course none of our patients had normal hearts, and this may account for the difference.

The intrinsic heart rate in our subjects was mostly below 100 beats a minute, and the permitted difference in our analysis of results of \pm 4 beats a minute between successive tests was chosen in order to straddle the implied 95 per cent confidence limits of Jose (i.e. $2 \times$ SD or $\pm 4 \%$, "normal" distribution assumed). In fact only a minority of our subjects showed consistency of this order throughout the period of analysis, and comparison of heart rates in single minutes on successive days showed considerable variation, $28-43$ per cent differing by 5 beats or more depending on how the results are treated (Table III). Better agreement can be obtained by comparing mean values over 5 -minute periods, but even so about one-third of our patients show differences well above \pm 4 beats a minute. However, the need for a manoeuvre of this sort merely reinforces the suspicion that the heart rate cannot be truly "fixed" in these patients. In addition, it should be recalled that our subjects were at rest in bed, and a certain similarity of heart rate, both in any single test or in duplicate tests, is probably inevitable.

It seems, therefore, that whatever the degree of pharmacological blockade produced by this test, 
in patients with heart disease, the heart rate which results is not always a consistent entity. In our view the administration of yet larger quantities of propranolol and atropine intravenously in pursuit of better blockade should only be undertaken, if at all, in healthy subjects. Severe hypotension was produced in two of our patients, presumably by the propranolol, and in the presence of important heart disease this is dangerous.

Our data are insufficient to confirm the interesting relation between intrinsic heart rate and myocardial disorder which Jose described, but the inconsistencies in heart rate found in several patients suggest that the significance of isolated observations of intrinsic heart rate and of serial changes in its value should be interpreted with caution.

\section{SUMMARY}

The heart rate after combined vagal and sympathetic blockade by intravenous atropine and propranolol (the "intrinsic heart rate") was studied in 19 patients with heart disease. During the period 4-15 minutes after injection inconsistencies in heart rate greater than \pm 4 beats a minute were found in 15 out of 49 tests, especially in the presence of atrial fibrillation. In the majority of tests a slow decline in heart rate was noted over the period of observation. Despite a careful attempt to eliminate any factor known to affect the "intrinsic heart rate", successive daily tests revealed differences greater than \pm 4 beats a minute in over half the subjects, and in 28-43 per cent of all matched minute comparisons, depending on the mode of analysis. In some subjects these differences were large. Sideeffects included hypotension which was hazardous in two instances. It is concluded that the "intrinsic heart rate" is not a highly reproducible value in all patients with heart disease and that the test itself may be dangerous.

We thank Dr. Walter Somerville for his encouragement and advice, and Dr. J. D. Fitzgerald of I.C.I. Ltd. for his helpful comments.

\section{REFERENCES}

Frick, M. H., Heikkilä, J., and Kahanpää, A. (1967). Combined parasympathetic and beta-receptor blockade as a clinical test. Acta med. scand., 182, 621.

Jose, A. D. (1966). Effect of combined sympathetic and parasympathetic blockade on heart rate and cardiac function in man. Amer. F. Cardiol., 18, 476. 